\title{
IgG4-related dacryoadenitis and sialadenitis
}

INSERM

\section{Source}

INSERM. (1999). Orphanet: an online rare disease and orphan drug data base. Ig G4related dacryoadenitis and sialadenitis. ORPHA:79078

Ig G4-related dacryoadenitis and sialoadenitis (Mikulicz disease) is an Ig G4-related sclerosing disease (see this term) characterized by persistent, usually painless, bilateral enlargement of the lacrimal, parotid, and submandibular glands associated with elevated levels of serum immunoglobulin (Ig) G4 and with lymphocyte and Ig G4-positive plasmacyte infiltration. It predominantly causes mouth and eye dryness but can also affect other organs such as the lungs, liver, and kidneys, and be accompanied by complications such as autoimmune pancreatitis (AIP), retroperitoneal fibrosis, and tubulointerstitial nephritis (see these terms). 